\title{
IMPLIKASI PROFESIONALISME GURU TERHADAP PENGEMBANGAN KARAKTER PESERTA DIDIK DI SMP FAUZANIYYAH KECAMATAN SUKARESMI KABUPATEN GARUT
}

Masykur

\section{STKIP GARUT}

\begin{abstract}
ABSTRAK - Penelitian ini bertitik tolak dari permasalahan dalam pembelajaran di sekolah, di antaranya banyak guru yang dari segi profesionalismenya masih rendah, sehingga hal ini akan berdampak buruk pada pengembangan karakter peserta didik, padahal guru merupakan orang yang memiliki peran sangat penting dalam pembentukan dan pengembangan karakter peserta didik.Hal ini tentunya menimbulkan asumsi bahwa semakin tinggi profesionalisme guru maka karakter peserta didik akan semakin berkembang dengan baik. Penelitian inibertujuan untuk mengetahui seberapa besar implikasi profesionalisme guru terhadap pengembangan karakter peserta didik khusunya di sekolah yang diteliti yaitu di SMP Fauzaniyyah yang berada di desa Sukaresmi, Kecamatan Sukaresmi, Kabupaten Garut.Permasalahan dalam penelitian ini penulis batasi sebagai berikut: (1) Bagaimana tingkat profesionalisme guru di SMP Fauzaniyyah, Sukaresmi?; (2) Bagaimana karakter peserta didik di SMP Fauzaniyyah, Sukaresmi?; (3) Bagaimana strategi pengembangan karakter peserta didik di SMP Fauzaniyyah, Sukaresmi ?; (4) Bagaimana implikasi profesionalisme guru terhadap pengembangan karakter peserta didik di SMP Fauzaniyyah, Sukaresmi? Metode penelitian yang digunakan adalah metode deskriptif korelatif, dengan teknik pengumpulan data yang digunakan antara lain observasi, wawancara, angket dan studi literatur. Berdasarkan hasil analisis terhadap data yang terkumpul, maka penulis menarik beberapa kesimpulan sebagai berikut: (1)Profesionalisme guru di SMP Fauzaniyyah Sukaresmi, Garut, berdasarkan hasil analisis statistik berada pada pada taraf baik dengan perhitungannya sebagai berikut: 1977:30:16 = 4,1. Nilai tersebut berada pada kategori baik karena berada pada rentang antara 3,5 - 4,5 dengan kategori baik. (2) Karakter peserta didik di SMP Fauzaniyyah Sukaresmi berdasarkan hasil analisis statistik menunjukkan bahwa nilai variabel pengembangan karakter
\end{abstract}

peserta didik di SMP Fauzaniyyah Sukaresmi, Garut berkategori baik dengan perhitungan sebagai berikut: 1992:30:16 = 4,15. Nilai tersebut berada pada rentang antara 3,5-4,5 dengan kategori baik. (3)Implikasi profesionalisme guru terhadap pengembangan karakter peserta didik di SMP Fauzaniyyah Sukaresmi, Garut, berdasarkan hasil analisis statistik mempunyai implikasi yang cukup, hal ini terbukti dengan hasil uji korelasi dari kedua variabel yang diperoleh koefisien korelasi 0,49. Koefisien tersebut berada pada koefisien 0,41 0,60, yaitu korelasi yang cukup.(4) Berdasarkan hasil uji hipotesis thitung dan tabel diperoleh hasil bahwa $t_{\text {hitung }}>t_{\text {tabel, }}$ yaitu 3,24 $>2,05$ dengan derajat kebebasan 27 taraf signifikansi 0,05 (5\%). Hal ini berarti bahwa variabel $X$ (profesionalisme guru) mempunyai hubungan yang cukup signifikan dengan variabel $Y$ (pengembangan karakter peserta didik).

Kata-kata kunci: Profesionalisme, Guru, Karakter, Peserta didik 


\section{PENDAHULUAN}

Proses belajar mengajar merupakan inti dari proses pendidikan secara keseluruhan dengan guru sebagai pemegang peran utama. Guru memiliki peranan yang sangat besar dalam menciptakan generasi bangsa yang unggul dari segi akhlak atau keperibadian yang menerapkan nilai-nilai karakter serta intelektual peserta didiknya. Peranan ini membutuhkan tanggung jawab yang besar serta ilmu yang memadai. Tanpa keterampilan dan kecerdasan yang didukung oleh kesabaran serta pemahaman terhadap karakter peserta didiknya, seorang guru akan mengalami kesulitan dalam membentuk generasi yang unggul sesuai harapan sebagaimana yang dicita-citakan bangsa dan Negara.

Pendidikan bermaksud membantu peserta didik untuk menumbuhkembangkan potensi-potensi kemanusiaannya. Itulah sebabnya saat ini tugas guru tidak hanya mengajar sesuai jadwal yang telah ditentukan, tetapi dituntut profesionalitas untuk mengembangkan potensi dirinya sebagai pendidik, pembimbing, instruktur atau pelatih, penilai serta pengevaluasi dalam dunia pendidikan. Guru dituntut untuk memenuhi suatu standar kualitas profesional agar proses pendidikan dan pengajaran terhadap peserta didik mencapai hasil yang optimal.

"Profesional berarti sifat sesuatu yang berkenaan dengan profesi; penampilan dalam menjalankan jabatan sesuai dengan tuntutan profesi; orang yang mempunyai kemampuan sesuai dengan tuntutan profesi” (Soetjipto dan Kosasi, 2009:262). Sudjana (1988) dalam

Usman (2009:14) mengatakan bahwa: "Pekerjaan yang bersifat profesional adalah pekerjaan yang hanya dapat dilakukan oleh mereka yang khusus dipersiapkan untuk itu dan bukan pekerjaan yang dilakukan oleh mereka yang karena tidak dapat memperoleh pekerjaan lain.” Selanjutnya Sudjana (1988) dalam Usman (2009:14) mengatakan bahwa: "Pekerjaan yang bersifat profesional adalah pekerjaan yang hanya dapat dilakukan oleh mereka yang khusus dipersiapkan untuk itu dan bukan pekerjaan yang dilakukan oleh mereka yang karena tidak dapat memperoleh pekerjaan lain”."Gurudapat diartikan sebagai pendidik profesional dengan tugas utamanya adalah mendidik, mengajar, membimbing, mengarahkan, melatih, menilai dan mengevaluasi peserta didik." (Aqib, 2013:99).

"Guru dapat diartikan sebagai pendidik profesional dengan tugas utamanya adalah mendidik, mengajar, membimbing, mengarahkan, melatih, menilai dan mengevaluasi peserta didik." (Aqib, 2013:99). Berdasarkan pengertian di atas, maka pengertian guru profesional adalah "orang yang memiliki kemampuan dan keahlian khusus dalam bidang keguruan sehingga ia mampu melakukan tugas dan fungsinya sebagai guru dangan kemampuan maksimal." (Usman, 2009:15). Dalam Kamus Besar Bahasa Indonesia (KBBI), Pusat Bahasa Departemen Pendidikan Nasional:"Karakter berarti sifat-sifat kejiwaan, akhlak atau budi pekerti yang membedakan seseorang dengan yang lain, atau bermakna bawaan, hati, jiwa, kepribadian, budi pekerti, perilaku, personalitas, sifat, tabiat, tempramen, watak." (Gunawan, 2012:2). Peserta didik dapat diartikan: "Orang yang menerima pengaruh dari seseorang atau sekelompok orang yang menjalankan pendidikan.” (Jauhari dkk, 2011:10). Selain itu, peserta didik juga dapat diartikan sebagai: "Seseorang yang menjadi saasaran pokok (subjek) dalam pendidikan; biasa pula disebut murid, siswa, mahasiswa, warga belajar, dan lain-lain” (Tirtaraharjda, 2005:128).

Seorang guru dapat dikatakan sebagai guru yang profesional jika mereka mampu menghasilkan anak didik yang beda dari lainnya. Maksudnya seorang guru yang profesional harus bisa menjadikan anak didikya memiliki pengetahuan yang luas serta mampu menguasai pelajaran yang diberikan dengan sebaik-baiknya. Seorang guru 
yang profesional dituntut untuk mampu membuat suatu terobosan baru tentang sistem pembelajaran. Tentang bagaimana cara membuat suatu metodologi pembelajaran yang efektif untuk diterapkan kepada anak didiknya.

Berdasarkan pemaparan di atas, penulis sangat tertarik dengan pembahasan yang berkaitan dengan masalah profesionalisme guru dan karakter peserta didik.Penulis berpendapat bahwa ada hubungan sebab akibat antara profesionalisme guru dengan pengembangan karakter peserta didik. Selain itu, penulis juga beranggapan bahwa kegagalan pendidikan diIndonesia salah satu penyebabnya adalah tingkat profesionalisme guru yang kurang baik. Untuk membuktikan hal di atas, maka penulis tertarik untuk melakukan penelitian di sekolah swasta tepatnya di SMP Fauzaniyyah Kecamatan Sukaresmi Kabupaten Garut.

Pada tataran kondisi di lapangan, SMP Fauzaniyyahyang beralamat di kompleks Pondok Pesantren Fauzan, merupakan salah satu Sekolah Menengah Pertama swasta di Desa Sukaresmi, Kecamatan Sukaresmi, Kabuapaten Garut yang sudah cukup lama berdiri, yaitu sejak tahun 1987. Sekolah ini berada di bawah naungan Yayasan Al Fauzaniyyah yang dibentuk oleh keluarga Pondok Pesantren yang memiliki basis di masyarakat yang sangat kuat.

Melihat kondisi di lapangan, tentunya ada beberapa hal yang menjadi pertimbangan, kenapa penulis tertarik untuk melakukan penelitian di SMP Fauzaniyyah Sukaresmi Garut:

1. Berpedoman pada UU RI Nomor 14 Tahun 2005 tentang Guru dan Dosen pasal 8, disebutkan bahwa sebagian dari kewajiban guru adalah memiliki kualifikasi akademik, kompetensi serta sertifikat pendidik. Dengan demikian, penulis ingin meneliti apakah guru-guru di SMP Fauzaniyyah sudah memenuhi kewajiban-kewajiban tersebut atau belum.

2. Guru yang mengajar di sekolah swasta terkadang tidak sesuai dengan latar belakang pendidikannya sehingga berdampak terhadap kualitas pendidikan. Dengan demikian penulis ingin mengetahuiapakah hal tersebut terjadi juga pada tenaga pengajar di SMP Fauzaniyyah Sukaresmi Garut atau tidak.

3. Seperti yang sudah penulis sebutkan sebelumnya, bahwa SMP Fauzaniyyah berada di kompleks Pondok Pesantren Fauzan dan sebagian tenaga pengajar merupakan keluarga dan alumni pesantren tersebut. Dengan demikian, penulis ingin mengetahui apakah kondisi seperti ini berimplikasi positif terhadap tingginya profesionalisme seorang guru sehingga nantinya berpengaruh juga pada pengembangan karakter peserta didik atau sama sekali tidak berpengaruh.

\section{RUMUSAN MASALAH DAN BATASAN} MASALAH

\section{Rumusan Masalah}

Berdasarkan latar belakang di atas, maka masalahnya dapat penulis rumuskan sebagai berikut: "Bagaimana implikasi profesionalisme guru terhadap pengembangan karakter peserta didik di SMP Fauzaniyyah Desa Sukaresmi Kecamatan Sukaresmi Garut?"

\section{Batasan Masalah}

Berdasarkan rumusan masalah tersebut, maka masalah dalam penelitian ini dapat penulis batasi sebagai berikut:

a. Bagaimana tingkat profesionalisme guru di SMP Fauzaniyyah, Sukaresmi?

b. Bagaimana karakter peserta didik di SMP Fauzaniyyah, Sukaresmi? 
c. Bagaiamana strategi pengembangan karakter peserta didik di SMP Fauzaniyyah, Sukaresmi?

d. Bagaimana implikasi profesionalisme guru terhadap pengembangan karakter peserta didik di SMP Fauzaniyyah, Sukaresmi?

\section{TINJAUAN PUSTAKA}

Dalam bahasa Indonesia, guru umumnya diartikan sebagai pendidik profesional dengan tugas utamanya adalah mendidik, mengajar, membimbing, mengarahkan, melatih, menilai dan mengevaluasi peserta didik. Hal ini sesuai dengan Undang-Undang RI Nomor 14 Tahun 2005 tentang Guru dan Dosen, tepatnya pada pasal 1 ayat 1, yang menyatakan bahwa: "Guru adalah pendidik profesional yang mendidik, mengajar, membimbing, mengarahkan, melatih, menilai dan mengevaluasi peserta didik pada pendidikan anak usia dini pada jalur pendidikan formal, pendidikan dasar, dan pendidikan menengah.” (Aqib, 2013:99).Pada pasal 2 ayat 1 disebutkan bahwa: "Guru mempunyai kedudukan sebagai tenaga profesional pada jenjang pendidikan dasar, pendidkan menengah, dan pendidikan anak usia dini pada jalur pendidikan formal yang diangkat sesuai dengan peraturan perundang-undangan.” (Aqib, 2013:100).

Profesional berarti: "Sifat sesuatu yang berkenaan dengan profesi; penampilan dalam menjalankan jabatan sesuai dengan tuntutan profesi; orang yang mempunyai kemampuan sesuai dengan tuntutan profesi” (Soetjipto dan Kosasi, 2009:262). Berdasarkan UU RI Nomor 14 Tahun 2005 tentang Guru dan Dosen, pasal 1 ayat 4: "Profesional adalah pekerjaan atau kegiatan yang dilakukan seseorang dan menjadi sumber penghasilan kehidupan yang memerlukan keahlian, kemahiran, atau kecakapan memenuhi standar mutu atau norma tertentu serta memerlukan pendidikan profesi.” (Aqib, 2013:99).
Kompetensi guru merupakan salah satu faktor yang mempengaruhi tercapainya tujuan pembelajaran dan pendidikan di sekolah.Menurut Oemar Malik (2008:40) mengatakan bahwa: "Guru akan mampu mengemban dan melaksanakan tanggungjawabnya tersebut, jika memiliki kompetensi yang relevan". Namun kompetesi itu dipengaruhi oleh faktor latar belakang pendidikan, pengalaman megajar, dan lamanya mengajar. Adapun kompetensi yang harus dimiliki seorang guru ada empat, yaitu kompetensi pedagogik, kompetensi kepribadian, kompetensi profesional dan kompetensi sosial.

"Kompetensi pedagogik adalah pemahaman guru terhadap anak didik, perencanaan, pelaksanaan pembelajaran, evaluasi hasil belajar, dan pengembangan anak didik untuk mengaktualisasikan sebagai potensi yang dimilikinya." (Wibowo dan Hamrin, 2012:110).Kompetensi kepribadian meliputi pribadi yang mantap dan stabil, dewasa, arif, berwibawa, dan berakhlak mulia, sehingga dapat dijadikan sebagai teladan. Ibnu Sahnun dalam Wibowo dan Hamrin(2012:114) berpandangan bahwa: "Seluruh sikap dan perbuatan seorang guru merupakan suatu gambaran dari kepribadian guru tersebut, asal dilakukan secara sadar meliputi pengetahuan, keterampilan, ideal dan sikap dan juga persepsi yang dimilikinya tentang orang lain".

Kompetensi profesional merpakan kemampuan dalam hal penguasaan guru atas materi pembelajaran secara luas dan mendalam. Menurut Wina Sanjaya (2006) yang dipertegas oleh Wibowo dan Hamrin dalam buku yang berjudul Menjadi Guru Berkarakter(2012:118), menyatakan: "Kompetensi profesional merupakan kompetensi atau kemampuan yang berhubungan dengan penyelesaian tugas-tugas keguruan”."Al-Ghazali berpendapat bahwa guru yang dapat diserahi tugas mendidik adalah guru yang selain cerdas dan 
sempurna akalnya, juga guru yang baik akhlaknya. Dengan akhlaknya yang baik ia dapat menjadi contoh dan teladan bagi para muridnya." (Aqib, 2011:58). Dari pendapat di atas, menunjukkan bahwa guru profesional adalah guru yang berkarakter.

Kompetensi sosial tercermin dalam kemampuan guru ketika berkomunikasi, menjalin kerja sama dan berinteraksi secara efektif dan efisien, baik dengan peserta didik, sesama pendidik, orang tua/wali, maupun dengan masyarakat sekitar. Menurut Buchari Alma (2008) yang dipertegas oleh Wibowo dan Hamrin (2012:124), yang menyatakan: "Kompetensi sosial adalah kemampuan guru untuk berkomunikasi dan berinteraksi secara efektif dengan lingkungan sekolah dan di luar sekolah".

Sementara dalam Kamus Besar Bahasa

Indonesia (KBBI), Pusat BahasaDepartemen Pendidikan Nasional:"Karakter berartisifat-sifat kejiwaan, akhlak atau budi pekerti yang membedakan seseorang dengan yang lain, atau bermakna bawaan, hati, jiwa, kepribadian, budi pekerti, perilaku, personalitas, sifat, tabiat, tempramen, watak." (Gunawan, 2012:2). Sedangkan berkarakter berarti memiliki karakter, memiliki kepribadian, berperilaku, bersifat, bertabiat dan berwatak.

Peserta didik dapat diartikan: "Orang yang menerima pengaruh dari seseorang atau sekelompok orang yang menjalankan pendidikan.” (Jauhari dkk, 2011:10). Selain itu, peserta didik juga dapat diartikan: "Seseorang yang menjadi saasaran pokok (subjek) dalam pendidikan; biasa pula disebut murid, siswa, mahasiswa, warga belajar, dan lainlain." (Tirtaraharjda, 2005:128).

Menurut Undang-Undang RI nomor 2 tahun 1989 yang ditetapkan pada tanggal 27 Maret 1989 pasal 1 ayat 6 disebutkan bahwa: "Peserta ddik adalah anggota masyarakat yang berusaha mengembangkan dirinya melalui proses pendidikan pada jalur, jenjang dan jenis pendidikan tertentu". (Amri, dkk, 2011:148). Di antara karakter peserta didik yang baik adalah taat asas, memiliki kreatifitas yang tinggi, tanggung jawab, dan kecerdasan emosional. Karakter taat asas bagi peserta didik tercermin pada sikap ketaatan kepada setiap aturan yang berlaku dan sikap disiplin yang tinggi. "Disiplin disini bukan sekedar konsisten, tetapi lebih kepada mengikuti prosedur dan langkah-langkah pembelajaran secara tertib dan prosedural" (Suyadi, 2013:123).

Kreatif dapat dideskripsikan: "Berpikir dan melakukan sesuatu untuk menghasilkan cara atau hasil baru dari sesuatu yang telah dimiliki" (Wibowo, 2013:14). Kegiatan peserta didik dalam menghubungkan materi pelajaran di dalam kelas ke dalam pengalaman hidup sehari-hari, bukan sekedar memerlukan kemampuan intelektual namun diperlukan juga kemampuan kreatifitas yang tinggi.

Tanggung jawab dapat diartikan: "Sikap dan perilaku seseorang untuk melaksanakan tugas dan kewajibannya, yang seharusnya dia lakukan terhadap diri sendiri, masyarakat, lingkungan (alam, sosial dan budaya), negara dan Tuhan Yang Maha Esa" (Wibowo dan Hamrin, 2012:46). Kesediaan untuk menanggung segenap akibat dari perbuatan, merupakan indikasi dari sifat orang yang bertanggung jawab.

Kecerdasan emosional merupakan salah satu modal utama yang harus dimiliki peserta didik ketika mereka bergaul dalam kehidupan sehari-hari terutama ketika berada di lingkungan sekolah. Saat peserta didik berada di lingkungan sekolah, kecerdasan emosional tercermin dalam sikap sabar dan sikap toleransi yang tinggi baik. Peserta didik yang memiliki kecerdasan emosional tidak akan mudah marah dan mudah tersinggung, walaupun ketika ada teman sekolah yang berseleisih faham dengannya. 


\section{METODE PENELITIAN}

Metode penelitian dalam setiap karya tulis ilmiah mutlak diperlukan karena merupakan cara untuk mengumpulkan data yang sesuai penggunaannya untuk menguji hipotesis. Menurut Winarto Surakhmad (1990:131): “... metode merupakan cara utama menguji serangkaian hipotesa dengan menggunakan serta alat-alat tertentu. Cara utama ini dipergunakan setelah penyelidikan memperhitungkan kewajarnnya ditinjau dari tujuan penyelidikan serta situasi penyelidikan".

\section{Metode Penelitian}

Metode yang akan digunakan pada penelitian ini adalah metode deskriptif korelatif. "Metode deskriptif adalah metode penelitian yang dimaksudkan untuk mengumpulkan informasi mengenai status suatu gejala yang ada yaitu keadaan gejala menurut apa adanya pada saat penelitian dilakukan" (Arikunto,1998:239).Sedangkan yang dimaksud dengan korelasi adalah suatu alat statistik yang dapat digunakan untuk membandingkan hasil pengukuran dua variabel agar dapat menentukan tingkat hubungan antara variabel-variabel. Jadi dapat disimpulkan bahwa metode deskriptif korelatif adalah mengumpulkan data yang berhubungan dengan masalah yang sedang berlangsung saat ini, kemudian mencari keterhubungan atau korelasi diantara variabel-variabelnya" (Suharsimi Arikunto, 2006:270).

\section{Populasi dan Sampel}

"Populasi adalah wilayah generalisasi yang terdiri atas:obyek / subyek yang mempunyai kualitas dan karakteristik tertentu yang ditetapkan oleh peneliti untuk dipelajari dan kemudian ditarik kesimpulannya." (Sugiyono, 2013:117). Populasi dalam penelitian ini adalahguru sebanyak 33 orang.dan peserta didik kelas VIII SMP Fauzaniyyah, Sukaresmi, Garut yang jumlahnya 259 orang.

"Sampel adalah bagian dari jumlah dan karakteristik yang dimiliki pleh populasi tersebut." (Sugiyono, 2013:118).Sampel pada penleitian ini adalah tiga orang guru untuk diwawancaraiyang meliputi wakil kepala sekolah bidang kurikulum, bidang kesiswaan dan guru BK. Sedangkan angket akan desebarkan kepada 30 orang peserta didik atau sekitar $12 \%$ dari jumlah populasi. Sehingga jumlah sampel adalah 33 orang.

\section{Teknik Pengumpulan Data}

\section{a. Kuesioner (angket)}

"Kuesioner adalah teknik pengumpulan data yang dilakukan dengan cara memberi seperangkat pertanyaan atau pernyataan tertulis kepada responden untuk dijawabnya." (Sugiyono, 2013: 199). Angket ini akan disebarkan kepada 30 peserta didik kelas VIII SMP Fauzaniyyah, Kecamatan Sukaresmi, Kabupaten Garut..

\section{b. Observasi}

"Observasi adalah kegiatan mempelajari suatu gejala dan peristiwa melalui upaya mengamati dan mencatat data atau informasi secara sistematis." (Sudjana, 2010:292). Sebagai metode yang meliputi kegiatan pemusatan perhatian terhadap suatu objek dengan menggunakan seluruh alat indera. "Jadi observasi dapat melalui penglihatan, penciuman, pendengaran, peraba dan pengecap." (Suharsimi Arikunto, 1998:146). Observasi akan dilakukan secara langsung ke lokasi penelitian yaitu SMP Fauzaniyyah yang beralamat di Komplek Ponpes Fauzan, Kecamatan Sukaresmi, Kabupaten Garut.

\section{c. Wawancara}


"Wawancara adalah sebuah dialog yang dilakukan oleh pewawancara untuk memperoleh informasi dari terwawancara." (Suharsimi Arikunto, 1998:145). Pada awalnya wawancara akan akan dilakukan penulis terhadap kepala sekolah, namun berhubung sedang melaksanakan ibadah haji, maka peneliti akan mewawancarai wakil kepala sekolah bidang kurikulum, bidang kesiswaan dan guru BK.

\section{d. Studi literatur}

"Studi literatur adalah mencari data melalui literatur yang berhubungan dengan penelitian melalui buku, catatan, transkip, surat kabar, majalah, atau kepustakaan lainnya." (Suharsimi Arikunto, 2006:230). Studi literatur ini berupa buku dan artikel dari internet.

\section{Teknik Analisis Data}

\section{a. Análisis Parsial}

Tahapan ini dimaksudkan untuk memberikan gambaran dari realisasi kondisi tentang masing-masing variabel, baik variabel "profesionlisme guru" (X) maupun variabel "pengembangan karakter peserta didik" (Y).Adapun penganalisaan dalam kegiatan ini ditempuh beberapa langkah diantaranya sebagai berikut:

1) Menentukan kriteria tinggi rendahnya kualifikasi variabel profesionalisme guru dan kualifikasi variabel pengembangan karakter peserta didik, dengan menggunakan kriteria sebagai berikut:

a) Hasil skor antara $0,5-1,5$, berarti jelek sekali (JS)

b) Hasil skor antara 1,5-2,5, berarti jelek (J) c) Hasil skor antara 2,5-3,5, berarti cukup (C)

d) Hasil skor antara 3,5-4,5 berarti baik (B)

e) Hasil skor antara 4,5-5,5 berarti baik sekali (BS)

(Sudjana, 2004:135)

2) Menguji normalitas kurva, dengan langkah-langkah sebagai berikut:

a) Mencari rata-rata (Mean) dari variabel $\mathrm{X}$ dan variabel $\mathrm{Y}$ dengan rumus sebagai berikut:

Untuk variabel $(\mathrm{X})=\mathrm{Me} \quad(\mathrm{X})=$ $\bar{x}=\frac{\sum f_{i} x_{i}}{\sum f_{i}}$

Untuk variabel $(\mathrm{Y})=\mathrm{Me} \quad(\mathrm{Y})=$ $\bar{y}=\frac{\sum f_{i} y_{i}}{\sum f_{i}}$

(Subana, 2000:66)

b) Menentukan kelas interval, dengan rumus:

$\mathrm{K}=1+\log$ 3,3 n (Sudjana: 1998:47)

c) Menentukan panjang kelas interval, dengan rumus:

$\mathrm{P}=\mathrm{R}: \mathrm{K}$

Keterangan: $p=$ panjang kelas

$$
\begin{aligned}
& \mathrm{R}=\text { range } \\
& \mathrm{k}=\text { banyak }
\end{aligned}
$$

kelas

(Maryati, 2011:09)

d) Mencari standar deviasi, dengan rumus:

$S d=\sqrt{\frac{\sum f^{i}\left(X_{i}-\bar{x}\right)^{2}}{n-1}}$

(Sugiyono, 2011:58) 


$$
\begin{aligned}
& \text { e) Membuat tabel distribusi } \\
& \text { frekuensi } \\
& \text { f) Mencari harga chi-kuadrat } \\
& \text { hitung }(\mathrm{X}) \text { dengan rumus: } \\
& \mathrm{X}^{2}=\sum \frac{\left(O_{i}-E_{i}\right)^{2}}{E_{i}} \text { (Sudrajat, }
\end{aligned}
$$

2000:125)

g) Menentukan nilai X2tabel dengan menggunakan taraf kepercayaan $5 \%(0,05)$

h) Mencari derajat kebebasan, dengan rumus: $\mathrm{dk}=\mathrm{K}-3$

i) Membandingkan antara X2hitung dengan nilai X2tabel dengan keriteria uji normalitas sebagai berikut:

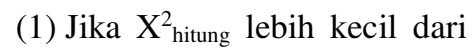
$\mathrm{X}_{\text {tabel, maka data }}^{2}$ berdistribusi normal, dalam arti memenuhi syarat

(2) Jika $X^{2}$ hitung lebih besar dari $\mathrm{X}_{\text {tabel, maka data }}^{2}$ berdistribusi tidak normal, dalam arti tidak memenuhi syarat.

\section{b. Análisis Product Moment}

Dalam análisis ini digunakan langkah-langkah sebagai berikut:

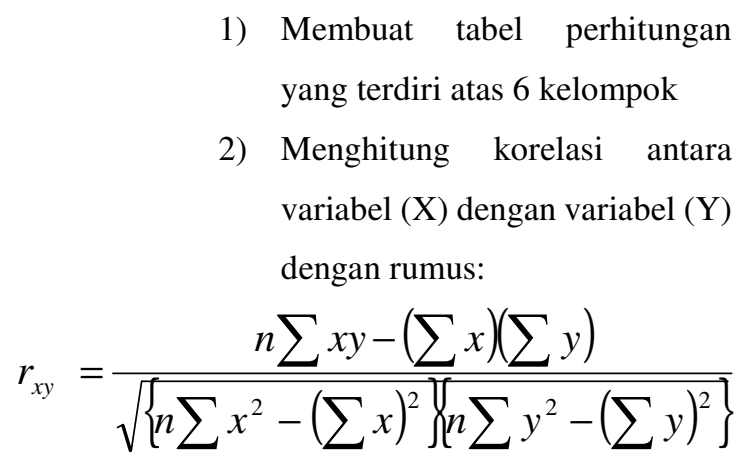

(Sugiyono, 2011:55)
3) Memberikan penafsiran atas Indeks koefisien korelasi Variabel (X) dengan Variabel (Y), berdasarkan klasifikasi tabel korelasi berikut:

TABEL 3.1

\begin{tabular}{|c|c|}
\hline Interval Koefisien & Tingkat Hubungan \\
\hline $0,00-0,199$ & Sangat rendah \\
$0,20-0,399$ & Rendah \\
$0,40-0,599$ & Sedang \\
$0,60-0,799$ & Kuat \\
$0,80-1,000$ & Sangat kuat \\
\hline
\end{tabular}

4) Menetapkan kontribusi determinasi variabel $\mathrm{X}$ (profesionalisme guru) terhadap variabel Y (pengembangan karakter peserta didik) dengan menggunakan rumus:

$$
\mathrm{KD}=\mathrm{r}^{2} \times 100 \%
$$

\section{HASIL PENELITIAN DAN PEMBAHASAN}

Berdasarkan perhitungan statitik mengenai tingkat profesionalisme guru di SMP Fauzaniyyah, maka hasil yang diperoleh adalah 1977:30:16 = 4,1 Skor ini termasuk kategori baik (B), karena berada di antara skala 3,5 - 4,5. Dengan demikian, tingkat profesionalisme guru di SMP Fauzaniyyah tergolong baik. Hal tersebut didukung oleh hasil wawancara dengan wakil kepala sekolah bidang kurikulum, yang menyatakan bahwa guru-guru di SMP Fauzaniyyah, dari segi profesionalisme sudah baik. Pernyataan tersebut salah satunya ditandai dengan latar belakang pendidikan guru di SMP Fauzaniyyah yang mayoritas lulusan dari perguruan tinggi ilmu keguruan dan pendidikan seperti STKIP, UPI dan fakultas tarbiyyah UIN Bandung.

Hal tersebut sesuai dengan pernyataan Abuddin (2003:41) yang mengatakan bahwa: "Sebagai pendidik profesional, guru bukan saja 
dituntut melaksanakan tugasnya secara profesional, juga harus memiliki pengetahuan dan kemampuan profesional'. UU RI Nomor 14 Tahun 2005 tentang Guru dan Dosen, pasal 1 ayat 4 yang mengatakan: "Profesional adalah pekerjaan atau kegiatan yang dilakukan seseorang dan menjadi sumber penghasilan kehidupan yang memerlukan keahlian, kemahiran, atau kecakapan memenuhi standar mutu atau norma tertentu serta memerlukan pendidikan profesi." (Aqib, 2013:99).

Berdasarkan perhitungan statitik mengenai pengembangan karakter peserta didik di SMP Fauzaniyyah,maka hasil yang diperoleh adalah 1992:30:16 $=4,2$. Skor ini termasuk kategori baik (B), karena berada di antara skala 3,5 - 4,5. Dengan demikian, pengembangan karakter peserta didik di SMP Fauzaniyyah tergolong baik. Hal di atas diperkuat pula dengan hasil wawancara dengan guru BP yang mengatakan bahwa karakter peserta didik di SMP Fauzaniyyah dari tahun ke tahun semakin membaik. Hal ini ditandai dengan berkurangnya jumlah pelanggaran yang dilakukan peserta didik. Hal senada disampaikan pula oleh wakil kepala sekolah bidang kesiswaan yang mengatakan bahwa pembinaan dan pengembangan karakter peserta didik selain melalui pembelajaran di kelas juga melalui kegiatan ekstrakurikuler dan kegiatan kepesantrenan.

Sejalan dengan hasil penelitian, Wibowo (2013:177) berpendapat: "Manajemen pendidikan karakter dengan bidang garap peserta didik, diwujudkan dalam bentuk program pembinaan peserta didik". Selain itu, dia juga mengatakan bahwa: "Implementasi pendidikan karakter bisa dilakukan melalui: a) terintegrasi dalam pembelajaran; b) terintegrasi dalam pengembangan diri melalui kegiatan ekstrakurikuler; dan c) terintegrasi dalam manajemen pendidikan." (Wibowo, 2013:15).
Berdasarkan uji korelasi diperoleh nilai korelasi sebesar 0,49. Sedangkan berdasarkan uji hipotesis diperoleh hasilnya sebesar 3,24, yang menunjukkan bahwa terdapat implikasi atau pengaruh yang cukup signifikan dari profesionalisme guru terhadap pengembangan karkater peserta didik. Hasil ini diperkuat dengan perhitungan kontribusi determinasi yang diperoleh hasil sebesar 24,01\%. Hasil ini menunjukkan bahwa sebesar 24,01\% pengembangan karakter peserta didik di SMP Fauzaniyyah Sukaresmi dipengaruhi oleh profesionalisme guru.

Hasil di atas diperkuat oleh pendapat Abuddin (2013:147) yang mengatakan: "Keberhasilan pendidikan sebagian besar ditentukan oleh mutu profesionalisme seorang guru". Najib dalam Zainal Aqib (2011:101) juga berpendapat bahwa: "Peran guru sangat penting dalam kegiatan di sekolah. Guru merupakan ujung tombak kegiatan di sekolah karena langsung berhadapan dengan siswa. Keberhasilan siswa sangat erat dengan penampilan guru dalam mengelola proses belajar mengajar di depan kelas". Sejalan dengan hal tersebut Suwarno dan Hasim(2009:79) mengatakan: “... guru yang tidak profesional pun sangat sulit untuk mengembangkan dan menanamkan kepribadian luhur kepada murid-muridnya”.

\section{SIMPULAN}

Adapun kesimpulan secara khusus, penulis berorientasi pada batasan masalah sebagaimana tercantum pada bab I. Berdasarkan hal itu, maka kesimpulan secara khusus yang dapat penulis sampaikan antara lain sebagai berikut:

1. Tingkat profesionalisme guru di SMP Fauzaniyyah Sukaresmi, Garut, berdasarkan hasil analisis statistik menunjukkan bahwa nilai variabel profesionalisme guru, berada pada taraf baik, dengan perhitungan sebagai berikut: 
1977:30:16 $=4,1$. Nilai tersebut berada pada kategori baik karena berada pada rentang antara 3,5 - 4,5. Maka dari itu, diperoleh bahwa tingkat profesionalisme guru di SMP Fauzaniyyah Sukaresmi sudah termasuk tinggi.

2. Karakter peserta didik di SMP Fauzaniyyah Sukaresmi, berdasarkan hasil analisis statistik menunjukkan bahwa nilai variabel pengembangan karakter peserta didik berada pada taraf baik dengan perhitungan sebagai berikut: 1992:30:16 = 4,15 . Nilai tersebut berada pada rentang antara 3,5-4,5 dengan kategori baik. Maka dari itu, diperolah hasil bahwa pengembangan karakter peserta didik di SMP Fauzaniyyah Sukaresmi, Garut sudah termasuk baik.

3. Strategi yang digunakan dalam mengembangkan karakter peserta didik di SMP Fauzaniyyah antara lain dengan mengintegrasikan pendidikan karakter pada tiap mata pelajaran, peningkatan kreatifitas melalui kegiatan ektrakurikuler, dan melalui koordinasi atau kerja sama yang intensif dengan pihak pondok pesantren.

4. Untuk mengetahui seberapa besar implikasi profesionalisme guru terhadap pengembangan karakter peserta didik di SMP Fauzaniyyah Sukaresmi, penulis melakukan pengujian dengan cara uji korelasi, uji hipotesis dan uji kontribusi determinasi. Berdasarkan hasil uji korelasi diperoleh hasil koefisien korelasi sebesar 0,49 . Koefisien tersebut berada pada koefisien 0,40 - 0,599, yaitu korelasi yang sedang atau cukup. Berdasarkan uji hipotesis diperoleh hasil bahwa $t_{\text {hitung }}>\mathrm{t}_{\text {tabel, }}$ yaitu 3,24 > 2,05 dengan derajat kebebasan
27 taraf signifikansi $0,05(5 \%)$. Hal ini berarti bahwa variabel $\mathrm{X}$ (profesionalisme guru) mempunyai hubungan yang cukup signifikan dengan variabel $\mathrm{Y}$ (pengembangan karakter peserta didik). Berdasarkan uji kontribusi determinasi,prosentase implikasi profesionalisme guru terhadap pengembangan karakter peserta didik diperoleh hasil sebesar $24,01 \%$. Hal ini menunjukkan bahwa masih terdapat $100 \%$ - $24,01 \%=75,99 \%$ faktor lain yang mempengaruhi pengembangan karakter perserta didik di SMP Fauzaniyyah Sukaresmi, Garut.

\section{DAFTAR PUSTAKA}

[1] Amri, dkk. (2011). Implementasi Pendidikan Karakter dalam Pembelajaran. Jakarta: Prestasi Pustaka Publisher.

[2] Aqib, Z. (2011). Pendidikan Karakter Membangun Perilaku Positif Anak Bangsa. Bandung: C.V. Yrama Widya.

[3] Aqib, Z. (2013). Pengembangan Keprofesian Berkelanjutan bagi Guru. Bandung: Yrama Widya.

4] Arikunto, S. (1998). Prosedur Penelitian Suatu Pendekatan Praktek. Jakarta: Rineka Cipta.

[5] Djamarah,S.B. (2005). Guru dan Anak Didik dalam Interaksi Edukatif. Jakarta: Rineka Cipta.

[6] El Moekry, M. (2009). Menjadi Guru Profesional dan Transformatif. Lamongan: Darul Ulum.

[7] Gunawan, H. (2012). Pendidikan Karakter Konsep dan Implementasi. Bandung: Alfabeta.

[8] Isjoni. (2009). Guru sebagai Motivator Perubahan. Yogyakarta: Pustaka Pelajar.

[9] Ma'arif, S. (2011). Mutiara-Mutiara Dakwah K.H. Hasyim Asy'ari. Bogor: Kanza.

[10] Maryati, N. (2011). Statistik. Diktat pada Program Studi PAI-IAILM Suryalaya Tasikmalaya. Tidak diterbitkan.

[11] Nata, A. (2003). Manajemen Pendidikan. Jakarta: Prenda Media. 
[12] Nuryata, I.M. (2010). Pembelajaran Masa Kini. Jakarta: Sekarmita.

[13] Purwanto, M.N. (1990). Psikologi Pendidikan. Bandung: Rosda.

[14] Qolawun, A.A. (2012). Rasulullah Saw; Guru paling Kreatif, Inovatif, \& Sukses Mengajar. Yogyakarta: Diva Press.

[15] Soetjipto, dan Kosasi, R. (2009). Profesi Keguruan. Jakarta: Rineka Cipta.

[16] Subana, dkk. (2000). Statistik Pendidikan. Bandung: Pustaka Setia.

[17] Sudjana. (2011). Manajemen Program Pendidikan. Bandung: Falah.

[18] Sugiyono. (2008). Statistik untuk Penelitian. Bandung: Alfabeta.

[19] Sugiyono. (2013). Metode Penelitian Pendidikan. Bandung: Alfabeta.

[20] Sulastri, A.S. (2010). Pengaruh Tingkat Status Sosial Ekonomi Orang Tua terhadap Hasil Belajar Siswa pada Pelajaran PKn di Kelas 1 SMP 1 Pameungpeuk. Skripsi pada Program Studi PPKn-STKIP Garut: Tidak diterbitkan.

[21] Sunarto, dan Hartono, A. (2006). Perkembangan Peserta Didik. Jakarta: Rineka Cipta.

[22] Sundayana, R. (2013). Komputasi Data Statistika. Garut: STKIP Garut Press.

[23] Suwarno, R.B. dan Hasim, A. (2009). Menjadi Guru yang Baik. Bandung: Pustaka Sutra.

[24] Suyadi. (2013). Strategi Pembelajaran Pendidikan Karakter. Bandung: Rosda.

[25] Tirtarahardja, U. dan La Sulo. (2005). Pengantar Pendidikan. Jakarta: Rineka Cipta.

[26] Wibowo, A. dan Hamrin. (2012). Menjadi Guru Berkarakter. Yogyakarta: Pustaka Pelajar. 